\title{
Status of soil properties in relationship with soil pH in Madhupur tract of Tangail district in Bangladesh
}

\author{
U Kumar $^{1 *}$, H Rashid ${ }^{2}$, NH Tithi ${ }^{2}$ and MY Mia ${ }^{2}$
}

${ }^{1}$ Soil Resource Development Institute, Tangail, Bangladesh; ${ }^{2}$ Department of Environmental Science and Resource Management, Mawlana Bhashani Science and Technology University, Santosh, Tangail 1902, Bangladesh.

\begin{abstract}
The study was intended to investigate the status of soil properties and its relation to soil $\mathrm{pH}$ in Madhupur tract soil of Tangail district, Bangladesh. Thirty soil samples were collected during the period from June-July, 2016 covering four types of land as high land, medium high land, medium low land and low land. The interpretative data showed that the range of $\mathrm{pH}$ was strongly acidic to slightly acidic (5.27- 5.90), mean $\mathrm{pH}$ was slightly acidic (5.61). The organic matter $(\mathrm{OM})$ status was medium (2.11 to $2.33 \%)$ and mean $\mathrm{OM}$ was medium $(2.24 \%)$. The Nitrogen $(\mathrm{N})$ status was low (0.11 to $0.13 \%)$ and mean $\mathrm{N}$ status was medium $(0.12 \%)$. The range of the Phosphorus (P) status was found very low to medium (1.63 to $11.06 \mu \mathrm{g} \mathrm{g}^{-1}$ soil) and mean P status was medium ( $7.37 \mu \mathrm{g} \mathrm{g}^{-1} \mathrm{soil}$ ). The Potassium (K) status was low to very high $(0.15$ to $0.75 \mathrm{meq} / 100 \mathrm{~g}$ soil $)$ and mean $\mathrm{K}$ status was low $(0.18 \mathrm{meq} / 100 \mathrm{~g}$ soil). The range of the Sulfur (S) status was found from low to medium (11.73 to $16.31 \mu \mathrm{g} \mathrm{g}^{-1}$ soil), mean S status was low (13.26 $\mu \mathrm{g} \mathrm{g}^{-1}$ soil). The range of the Zinc (Zn) status was found from medium to high (0.96 to $2.23 \mu \mathrm{g} \mathrm{g}^{-1}$ soil), mean $\mathrm{Zn}$ status was optimum (1.55 $\mu \mathrm{g} \mathrm{g}^{-1}$ soil). The range of the Boron (B) status was found from medium to very high (0.39 to $0.86 \mu \mathrm{g} \mathrm{g}^{-1}$ soil), mean B status was high ( $0.73 \mu \mathrm{g} \mathrm{g}^{-1}$ soil). The Calcium (Ca) status was medium to optimum (4.42 to $5.23 \mathrm{meq} / 100 \mathrm{~g}$ soil), mean Ca status was optimum (4.83 meq/100 g soil). The Magnesium (Mg) status was optimum to high (1.21 to $1.75 \mathrm{meq} / 100 \mathrm{~g}$ soil), mean $\mathrm{Mg}$ status was optimum (1.37 meq/100 g soil). No significant correlation of $\mathrm{OM}$ and other nutrients with $\mathrm{pH}$.
\end{abstract}

Key words: Soil properties, $\mathrm{pH}$, organic matter, nitrogen, phosphorus

Progressive Agriculturists. All rights reserved

*Corresponding Author: uksrdi@yahoo.com

\section{Introduction}

Soils of Bangladesh have been formed from different kinds of parent materials occurring in various topographic and drainage conditions. They are spread over three major physiographic units: (i) northern and eastern hills of Tertiary formations, covering $12 \%$ of the total area, (ii) Pleistocene terraces of Madhupur and Barind tracts, covering $8 \%$ of the total area, and (iii) Recent floodplains, mainly comprising alluvial sediments of the Ganges, Brahmaputra, and Meghna river systems, and occupying $80 \%$ of the country
(Saheed, 1984; Islam et al., 2017a,b)). Madhupur Tract is also known as Bhawal Garh and Madhupur Garh. Madhupur formation represents highly oxidized reddish brown clay containing ferruginous nodules and manganese spots. The higher level lands are known as Chala, are used to cover by forests specially named as Sal forest and the valleys are called Baid, used for Boro rice cultivations in the dry season by impounding the water for irrigation. These are also extensively uses for upland crops like fruit garden (Jackfruit, Pineapple, 


\section{Soil properties and its relation to $\mathrm{pH}$}

Banana, Mango, Bengal Olive, Pomelo, Star apple etc.), vegetables and year round crops (Sugarcane, Turmeric, Ginger etc.). The soil acidity is increased day by day in this area due to decreasing organic matter status because of intensive use of land (Karim et al., 1994). The most common tree is the Sal (Shorea robusta), a major source of timber and fuel (Hossain et al., 2010). Agricultural production is the main economic activity in our country. So, nutrient status of soil and their suitability maximum crop production should be ensured for better economic development of the country (ADAB News, 1979). The study was therefore, carried out: (i) to assess the soil organic matter and nutrients status (OM, N, P, K, S, Zn, B, Ca and $\mathrm{Mg}$ ) of Madhupur Tract soil, and (ii) to determine soil $\mathrm{pH}$ and find out its relation to others nutrients.

\section{Materials and Methods}

The study was conducted during the period of June to December, 2016 in Madhupur Tract. The study area lies between $23^{\circ} 48^{\prime}$ to $25^{\circ} 14^{\prime}$ North Latitudes and $89^{\circ} 46^{\prime}$ to $90^{\circ} 50^{\prime}$ East Longitudes at the four upazila of Tangail district, Bangladesh. The study area was divided into four types of land namely high land, medium high land, medium low land and low land. Soil samples were collected from the agricultural land of the above four land types. The samples were collected from the study area within a depth of $15 \mathrm{~cm}$ (top soil). Total 30 soil samples were collected from different areas of these upazilas. The collected soil samples (500 g) were air dried, grind and sieved for analysis. In this study, the $\mathrm{pH}$ was determined by electrometric method (Davis and Freitas, 1970). The organic matter of the soil sample was measured titrimetrically according to Walkley and Black's wet oxidation method (Walkley and Black, 1934). Total N content of soil was determined by Micro Kjeldahl method. Available phosphorus was extracted from the soil by shaking with $0.03 \mathrm{M} \mathrm{NH} 4 \mathrm{~F}-0.025 \mathrm{M} \mathrm{HCl}$ solution at $\mathrm{pH}<7.0$ following the method of Bray and Kurtz method (Bray and Kurtz, 1945). The available calcium $(\mathrm{Ca})$ and magnesium $(\mathrm{Mg})$ contents were extracted by ammonium acetate extraction method and determined by Ethylene-di-amine tetra acetic acid titration, Zinc of the soil sample was determined by ' $0.1 \mathrm{~N} \mathrm{HCl}$ (hydrochloric acid) extraction' method (Huq and Alam, 2005). The available sulphur in soil was determined by calcium chloride extraction method, Available potassium in soil was determined by ammonium acetate extraction method (Satter and Rahman, 1987). Boron was determined by hot water extraction method using a dilute calcium chloride solution (Berger and Truog, 1939). The Microsoft Office Excel software was used to present and interpret the collected data.

\section{Results and Discussion}

Table 1 showed that the $\mathrm{pH}$ of high land (HL), medium high land (MHL), medium low land (MLL) and low land (LL) were strongly acidic (5.35), slightly acidic (5.90), slightly acidic (5.76) and strongly acidic (5.27) respectively. The range of $\mathrm{pH}$ was found strongly acidic to slightly acidic (5.27-5.90), mean $\mathrm{pH}$ of all the land typeswas slightly acidic (5.61). The optimum value of $\mathrm{pH}$ was found neutral (7.0) for the maximum crop production. Excessive acidity is detrimental to soil health. It increases soil toxicity and fixed available phosphorous (Hart et al. 2013). The $\mathrm{OM}$ values showed a negative correlation with $\mathrm{pH}(\mathrm{r}=$ $-0.045, \mathrm{p}<0.01)$ (Table 2). The organic matter (OM) status of the high land, medium high land, medium low land and low land were medium in all the land types $(2.11,2.31,2.33$ and $2.24 \%)$ respectively. The range of OM status was medium (2.11 to $2.33 \%$ ), mean OM status of all the land types was medium (2.24\%).

High (3.41\%) OM status is the highly suitable for crop production. The Nitrogen $(\mathrm{N})$ status of the high land, medium high land, medium low land and low land were low in all the land types $(0.11,0.12,0.12$ and 0.13 $\%$ ) respectively. The range of the $\mathrm{N}$ status was found low $(0.11$ to $0.13 \%)$, mean $\mathrm{N}$ status of all the land types was low $(0.12 \%)$. Optimum $(0.27 \%) \mathrm{N}$ status is the suitable for crop production (BARC, 2018). The Phosphorus (P) status of the high land, medium high 
land, medium low land and low land were medium, low, low and very low $(11.06,5.29,7.78$ and $1.63 \mu \mathrm{g} g$ ${ }^{1}$ soil) respectively. The range of the $\mathrm{P}$ status was found very low to medium (1.63 to $11.06 \mu \mathrm{g} \mathrm{g}^{-1}$ soil), mean $\mathrm{P}$ status of all land types was medium (7.37 $\mu \mathrm{g} \mathrm{g}^{-1}$ soil). Optimum (15.75 $\mu \mathrm{g} \mathrm{g}^{-1}$ soil) $\mathrm{P}$ status in the soil is suitable for crop production. The Potassium $(\mathrm{K})$ status of the high land, medium high land, medium low land and low land were medium, low, medium and very high $(0.23,0.15,0.19$ and $0.75 \mathrm{meq} / 100 \mathrm{~g}$ soil) respectively. The range of $\mathrm{K}$ status wasfound low to very high $(0.15$ to $0.75 \mathrm{meq} / 100 \mathrm{~g}$ soil), mean $\mathrm{K}$ status of all the land types was low $(0.18 \mathrm{meq} / 100 \mathrm{~g}$ soil $)$. Optimum $(0.27 \mathrm{meq} / 100 \mathrm{~g}$ soil $) \mathrm{K}$ status in soil is suitable for crop production. The Sulfur (S) status of the high land, medium high land, medium low land and low land were low, low, medium and medium (13.15, $11.73,16.31$ and $15.71 \mu \mathrm{g} \mathrm{g}^{-1}$ soil) respectively. The range of the Sulfur (S) status was found low to medium (11.73 to $16.31 \mu \mathrm{g} \mathrm{g}^{-1}$ soil), mean $\mathrm{S}$ status of all the land types was low (13.26 $\mu \mathrm{g} \mathrm{g}^{-1}$ soil). Optimum (22.51 $\mu g \mathrm{~g}^{-1}$ soil) $\mathrm{S}$ status in soil is suitable for crop production.

Table 1. Status of the soil properties of Madhupur Tract soil (MT).

\begin{tabular}{|c|c|c|c|c|c|c|}
\hline Soil nutrient & $\begin{array}{l}{ }^{*} \mathrm{HL} \\
\text { Mean }( \pm \mathrm{SD})\end{array}$ & $\begin{array}{l}* * \text { MHL } \\
\text { Mean }( \pm \mathrm{SD})\end{array}$ & $\begin{array}{l}* * * \text { MLL } \\
\text { Mean }( \pm \mathrm{SD})\end{array}$ & $\begin{array}{l}* * * * \text { LL } \\
\text { Mean }( \pm \mathrm{SD})\end{array}$ & $\begin{array}{l}\text { Average } \\
( \pm \mathrm{SD})\end{array}$ & Optimum \\
\hline $\mathrm{pH}$ & $5.35( \pm 0.8)$ & $5.90( \pm 0.54)$ & $5.76( \pm 0.23)$ & $5.27( \pm 0.45)$ & $5.61( \pm 0.65)$ & 7.0 \\
\hline Status & $\begin{array}{l}\text { Strongly } \\
\text { acidic }\end{array}$ & $\begin{array}{l}\text { Slightly } \\
\text { acidic }\end{array}$ & $\begin{array}{l}\text { Slightly } \\
\text { acidic }\end{array}$ & $\begin{array}{l}\text { Strongly } \\
\text { acidic }\end{array}$ & $\begin{array}{l}\text { Slightly } \\
\text { acidic }\end{array}$ & Neutral \\
\hline $\mathrm{OM}(\%)$ & $2.11( \pm 0.47)$ & $2.31( \pm 0.45)$ & $2.33( \pm 0.48)$ & $2.24( \pm 0.34)$ & $2.24( \pm 0.44)$ & 3.41 \\
\hline Status & Medium & Medium & Medium & Medium & Medium & High \\
\hline N (\%) & $0.11( \pm 0.02)$ & $0.12( \pm 0.02)$ & $0.12( \pm 0.02)$ & $0.13( \pm 0.02)$ & $0.12( \pm 0.02$ & 0.27 \\
\hline Status & Low & Low & Low & Low & Low & Optimum \\
\hline $\mathrm{P}(\mu \mathrm{g} / \mathrm{g}$ soil $)$ & $11.06( \pm 9.52)$ & $5.29( \pm 2.19)$ & $7.78( \pm 4.21)$ & $1.63( \pm 1.01)$ & $7.37( \pm 6.74)$ & 15.75 \\
\hline Status & Medium & Low & Low & Very low & Low & Optimum \\
\hline $\mathrm{K}(\mathrm{meq} / 100 \mathrm{~g})$ & $0.23( \pm 0.11)$ & $0.15( \pm 0.05)$ & $0.19( \pm 0.08)$ & $0.75( \pm 0.15)$ & $0.18( \pm 0.08)$ & 0.27 \\
\hline Status & Medium & Low & Medium & Very high & Low & Optimum \\
\hline $\mathrm{S}(\mu \mathrm{g} / \mathrm{g}$ soil $)$ & $13.15( \pm 5.78)$ & $11.73( \pm 5.50)$ & $\begin{array}{l}16.31 \\
( \pm 9.66)\end{array}$ & $15.71( \pm 6.45)$ & $13.26( \pm 6.19)$ & 22.51 \\
\hline Status & Low & Low & Medium & Medium & Low & Optimum \\
\hline Zn $(\mu \mathrm{g} / \mathrm{g}$ soil $)$ & $1.56( \pm 0.59)$ & $1.49( \pm 0.87)$ & $0.96( \pm 0.30)$ & $2.23( \pm 2.07)$ & $1.55( \pm 0.94)$ & 1.35 \\
\hline Status & Optimum & Optimum & Medium & High & Optimum & Optimum \\
\hline B ( $\mu \mathrm{g} / \mathrm{g}$ soil $)$ & $0.73( \pm 0.24)$ & $0.86( \pm 0.15)$ & $0.61( \pm 0.14)$ & $0.39( \pm 0.36)$ & $0.73( \pm 0.25)$ & 0.45 \\
\hline Status & High & Very high & High & Medium & High & Optimum \\
\hline $\begin{array}{l}\mathrm{Ca}(\mathrm{meq} / 100 \mathrm{~g} \\
\mathrm{s})\end{array}$ & $4.56( \pm 3.77)$ & $5.23( \pm 2.43)$ & $4.42( \pm 2.66)$ & $4.76( \pm 2.06)$ & $4.83( \pm 2.88)$ & 4.51 \\
\hline Status & Optimum & Optimum & Medium & Optimum & Optimum & Optimum \\
\hline $\begin{array}{l}\mathrm{Mg}(\mathrm{meq} / \\
100 \mathrm{~g})\end{array}$ & $1.31( \pm 0.84)$ & $1.37( \pm 0.58)$ & $1.21( \pm 0.57)$ & $1.75( \pm 0.85)$ & $1.37( \pm 0.69)$ & 1.13 \\
\hline Status & Optimum & Optimum & Optimum & High & Optimum & Optimum \\
\hline
\end{tabular}

Note: $* \mathrm{HL}=\mathrm{High}$ Land; $* * \mathrm{MHL}=$ Medium High Land; $* * * \mathrm{MLL}=$ Medium Low Land; $* * *$ LL= Low Land 


\section{Soil properties and its relation to $\mathrm{pH}$}

The Zinc ( $\mathrm{Zn})$ status of the high land, medium high land, medium low land and low land were optimum, optimum, medium and high (1.56, 1.49, 0.96 and 2.23 $\mu \mathrm{g} \mathrm{g}^{-1}$ soil) respectively. The range of the $\mathrm{Zn}$ status was found medium to high (0.96 to $2.23 \mu \mathrm{g} \mathrm{g}^{-1}$ soil), mean $\mathrm{Zn}$ status of all the land types was optimum (1.55 $\mu \mathrm{g} \mathrm{g}$ ${ }^{1}$ soil). Optimum (1.35 $\mu \mathrm{g} \mathrm{g}^{-1}$ soil) $\mathrm{Zn}$ status in soil is suitable for crop production. The Boron (B) status of the high land, medium high land, medium low land and low land were high, very high, high and medium (0.73, $0.86,0.61$ and $0.39 \mu \mathrm{g} \mathrm{g}^{-1}$ soil) respectively. The range of the Boron (B) status was found medium to very high (0.39 to $0.86 \mu \mathrm{g} \mathrm{g}^{-1}$ soil), mean B status of all the land types was high $\left(0.73 \mu \mathrm{g} \mathrm{g}^{-1}\right.$ soil). Optimum $\left(0.45 \mu \mathrm{g} \mathrm{g}^{-1}\right.$ soil) B status in soil is suitable for crop production. The Calcium (Ca) status of the high land, medium high land, medium low land and low land were optimum, optimum, medium and optimum (4.56, 5.23, 4.42 and $4.76 \mathrm{meq} / 100 \mathrm{~g}$ soil) respectively. The range of the $\mathrm{Ca}$ status was found medium to optimum (4.42 to $5.23 \mathrm{meq} / 100 \mathrm{~g}$ soil), mean Ca status of all the land types was optimum (4.83 meq/100 g soil). Optimum (4.51meq/100 g soil) Ca status in soil is suitable for crop production.The Magnesium (Mg) status of the high land, medium high land, medium low land and low land were optimum, optimum, optimum and high (1.31, 1.37, 1.21 and $1.75 \mathrm{meq} / 100 \mathrm{~g}$ soil) respectively. The range of the $\mathrm{Mg}$ status was found optimum to high (1.21 to $1.75 \mathrm{meq} / 100 \mathrm{~g}$ soil), mean $\mathrm{Mg}$ status of all the land types was optimum (1.37 meq/100 g soil). Optimum (1.13 meq/100 $\mathrm{g}$ soil) $\mathrm{Mg}$ status in soil is suitable for crop production. The OM, N, P, K and S status were not suitable for agricultural crop production. But the $\mathrm{Zn}, \mathrm{B}, \mathrm{Ca}$ and $\mathrm{Mg}$ status were suitable for agricultural crop production in the study area.

The $\mathrm{N}, \mathrm{S}, \mathrm{B}, \mathrm{Mg}$ and $\mathrm{Ca}$ values showed a positive correlation with $\mathrm{pH}(\mathrm{r}=.053, .297, .032, .275$ and .210 ), on the other hand OM, $\mathrm{P}, \mathrm{Zn}$ and $\mathrm{K}$ values showed a negative correlation with $\mathrm{pH}(\mathrm{r}=-.045$, $.164,-.220$ and -.284). No significant correlation of $\mathrm{OM}$ and other nutrients with $\mathrm{pH}$ (Table 2). The $\mathrm{N}, \mathrm{P}, \mathrm{B}$,
$\mathrm{Zn}$ and $\mathrm{Ca}$ values showed a positive correlation with OM $(r=.827, .078, .191, .129$ and .218), on the other hand $\mathrm{S}, \mathrm{Mg}$ and $\mathrm{K}$ values showed a negative correlation with OM ( $\mathrm{r}=-.191,-.089$, and -.059). $\mathrm{N}$ value showed a significant correlation with OM ( $\mathrm{r}=$ $.827, \mathrm{p}<0.05$ ) (Table 2). The $\mathrm{Mg}, \mathrm{K}$ and $\mathrm{Ca}$ values showed a positive correlation with $\mathrm{N}(\mathrm{r}=.036, .110$, and .208), on the other hand $\mathrm{P}, \mathrm{S}, \mathrm{B}$ and $\mathrm{Zn}$ values showed a negative correlation with $\mathrm{N}(\mathrm{r}=-.040,-.195$, -.063 and -.016). No significant correlation of other nutrients with $\mathrm{N}$ (Table 2). The $\mathrm{B}$ and $\mathrm{Zn}$ values showed a positive correlation with $\mathrm{P}(\mathrm{r}=.161$, and .041 ), on the other hand $\mathrm{S}, \mathrm{Mg}, \mathrm{K}$ and $\mathrm{Ca}$ values showed a negative correlation with $\mathrm{P}(\mathrm{r}=-.130,-.488$, .190 and -.313). $\mathrm{Mg}$ value showed a significant correlation with $\mathrm{P}(\mathrm{r}=-.488, \mathrm{p}<0.05)$ (Table 2). The $\mathrm{Zn}, \mathrm{Mg}, \mathrm{K}$ and $\mathrm{Ca}$ values showed a positive correlation with $\mathrm{S}(\mathrm{r}=.194, .196, .128$ and .049), on the other hand $\mathrm{B}$ value showed a negative correlation with $\mathrm{N}(\mathrm{r}=$ .252). No significant correlation of other nutrients with $\mathrm{S}$ (Table 2). The $\mathrm{Zn}$ value showed a positive correlation with $\mathrm{B}(\mathrm{r}=.304)$, on the other hand $\mathrm{Mg}, \mathrm{K}$ and $\mathrm{Ca}$ values showed a negative correlation with $\mathrm{P}$ ( $\mathrm{r}$ $=-.377,-.514$, and -.223). $\mathrm{Mg}$ and $\mathrm{K}$ values showed a significant correlation with $\mathrm{P}(\mathrm{r}=-.377, \mathrm{p}<0.01$ and $\mathrm{r}=$ -.514, $\mathrm{p}<0.05)($ Table 2). The $\mathrm{K}$ and $\mathrm{Ca}$ values showed a positive correlation with $\mathrm{Zn}(\mathrm{r}=.201$ and .056$)$, on the other hand $\mathrm{Mg}$ values showed a negative correlation with $\mathrm{P} \quad(\mathrm{r}=-.239)$. No significant correlation of other nutrients with $\mathrm{Zn}$ (Table 2). The K and $\mathrm{Ca}$ values showed a positive correlation with $\mathrm{Mg}$ ( $\mathrm{r}$ $=.111$ and .507). Ca value showed a significant correlation with $\mathrm{Mg}(\mathrm{r}=.507, \mathrm{p}<0.05)$ (Table 2). The $\mathrm{Ca}$ value showed a negative correlation with $\mathrm{K}(\mathrm{r}=$ .076). No significant correlation of other nutrients with $\mathrm{K}$ (Table 2).

Previous studies show that the range of $\mathrm{pH}$ status in Madhupur Tract soil was recorded very strongly acidic to slightly acidic (4.00 to 6.10), the range of OM status was very low to high (1.01 to $3.37 \%$ ), the range of $\mathrm{N}$ status was very low to medium (0.04-0.26\%), the range of $\mathrm{P}$ status was very low to very high (4.00 to 29.00 
$\mu \mathrm{g} / \mathrm{g}$ soil), the range of S status was low to very high (10.00 to $72.00 \mu \mathrm{g} / \mathrm{g}$ soil), the range of $\mathrm{Mg}$ status was very low to high $(0.50$ to $3.50 \mathrm{meq} / 100 \mathrm{~g}$ soil $)$, the range of $\mathrm{Ca}$ status was very low to medium ( 0.50 to $3.00 \mathrm{meq} / 100 \mathrm{~g}$ soil), the range of $\mathrm{K}$ status was very low to very high $(0.08$ to $0.72 \mathrm{meq} / 100 \mathrm{~g}$ soil $)$, the range of $\mathrm{B}$ status was low to very high $(0.17$ to 1.2 $\mu \mathrm{g} / \mathrm{g}$ soil) and the range of $\mathrm{Zn}$ status was recorded very low to medium ( 0.50 to $1.50 \mu \mathrm{g} / \mathrm{g}$ soil) (Uddin et al., 2016; SRDI, 2018).

Table 2. Correlation among the soil properties in Madhupur Tract soil (Values are shown as $\mathrm{r}=$ coefficient correlation).

\begin{tabular}{lllllllllll}
\hline & $\mathrm{pH}$ & $\mathrm{OM}$ & $\mathrm{N}$ & $\mathrm{P}$ & $\mathrm{S}$ & $\mathrm{B}$ & $\mathrm{Zn}$ & $\mathrm{Mg}$ & $\mathrm{K}$ & $\mathrm{Ca}$ \\
\hline $\mathrm{pH}$ & 1 & & & & & & & & & \\
$\mathrm{OM}$ & -.045 & 1 & & & & & & & & \\
$\mathrm{~N}$ & .053 & $.827^{* *}$ & 1 & & & & & & & \\
$\mathrm{P}$ & -.164 & .078 & -.040 & 1 & & & & & & \\
$\mathrm{~S}$ & .297 & -.191 & -.195 & -.130 & 1 & & & & & \\
$\mathrm{~B}$ & .032 & .191 & -.063 & .161 & -.252 & 1 & & & & \\
$\mathrm{Zn}$ & -.220 & .129 & -.016 & .041 & .194 & .304 & 1 & & & \\
$\mathrm{Mg}$ & .275 & -.089 & .036 & $-.488^{* *}$ & .196 & $-.377^{*}$ & -.239 & 1 & & \\
$\mathrm{~K}$ & -.284 & -.059 & .110 & -.190 & .128 & $-.514^{* *}$ & .201 & .111 & 1 & \\
$\mathrm{Ca}$ & .210 & .218 & .208 & -.313 & .049 & -.223 & .056 & $.507^{* *}$ & -.076 & 1 \\
\hline
\end{tabular}

** Correlation is significant at the 0.01 level. *. Correlation is significant at the 0.05 level.

\section{Conclusion}

The study was concluded that the mean of the $\mathrm{pH}$ indicated slightly acidic condition in all collected soils of the investigated area.This might be due to acidic parent materials, oxidation-reduction process and harvest of high-yielding crops. The OM status was medium but slightly decreasing trend. It might be intensive crop cultivation, more application of inorganic fertilizer and lack of incorporation of crop residues in the soils. The total $\mathrm{N}$ status was low in all the land types. It might be due to de-nitrification, leaching and immobilization of $\mathrm{N}$ from the soil.The $\mathrm{P}$ status was very low to medium. This might be due to soil acidity. Excessive soil acidity fixed the available $\mathrm{P}$ to the soil.The $\mathrm{K}$ status was low to very high. The $\mathrm{S}$ status of the study area was low to medium. The $\mathrm{Zn}$ status was found medium to high.The B status was found medium to very high. The $\mathrm{Ca}$ status was found medium to optimum and the $\mathrm{Mg}$ status was found optimum to high. This could be due to application of imbalanced fertilizer by the farmers. The study concluded that $\mathrm{pH}, \mathrm{OM}, \mathrm{N}, \mathrm{P}, \mathrm{K}$ and $\mathrm{S}$ status was not suitable for agricultural crop production on the contrary the average $\mathrm{Zn}, \mathrm{B}, \mathrm{Ca}$ and $\mathrm{Mg}$ status was suitable for agricultural crop production. Proper management of crops and soils are needed for attaining optimum soil nutrient status and soils should be tested on a regular basis to determine its condition.

\section{References}

ADAB News (1979). Agricultural Development Agencies in Bangladesh, Dhaka.

BARC (2018). Fertilizer Recommendation Guide, Soils Publication no. 42. Bangladesh Agricultural Research Council, Farmgate, Dhaka.

Berger KC, Truog E (1939). Boron determination in soils and plants.Ind. Eng. Anal. Ed. 11: 540 545.

Bray RH, Kurtz LT (1945). Determination of total, organic, and available forms of phosphorus in soils. Soil Science, 59: 39-45. 


\section{Soil properties and its relation to $\mathrm{pH}$}

Davis J, Freitas F (1970). In Physical \& Chemical Methods of Soil \& Water Analysis, FAO of United Nations, Rome, Soil Bulletin, 10, III-1 : 65-67.

Hart JM, Sullivan DM, Anderson NP, Hulting AG, Horneck DA, Christensen NW (2013). Soil Acidity in Oregon: Understanding and Using Concept for Crop Production EM 9061. OSU Extension. Corvallis, OR. 22p.

Hossain MZ, Saha ML, Aziz CB, Hoque S (2010). Effects of deforestation on the properties of soil of Sal forests in Bangladesh. The Dhaka University Journal of Biological Sciences, 19(1): $63-72$.

Huq SMI, Alam MD (2005). A Handbook on Analysis of Soil, Plant and Water. BACER-DU, University of Dhaka, Bangladesh, xii+246 pp.

Islam MA, MA Hasan, MA Farukh (2017a). Application of GIS in general soil mapping of Bangladesh. Journal of Geographic Information System, 9: 604-621.

Islam MA, MR Hasina, P Majumder, MT Hossain, R Khatun (2017b). Monitoring and assessment of physiocochemical parameters of soils and coals used in brick kilns and their impat on health and environment. Proceedings of the VIII International Agricultural Symposium"Agrosym 2017", Jahorina, Sarajevo, Bosnia \& Herzegovina. October 5-8/2017, P. 1689-1695.
Karim Z, Mia MMU, Razia S (1994). Fertilizer in the national economy and sustainable environmental development. Asia pacific journal of environment and development. 2:48-67.

Saheed SM (1984). Soils of Bangladesh. In: Proceedings of the International Symposium on Soil Test Crop Response studies, Bangladesh Agricultural Research Council and Soil Science Society of Bangladesh, Dhaka, Bangladesh.

Satter DMA Rahman MM (1987). Techniques of Soil Analysis. Dept. of Soil Sci. BAU, Mymensingh. pp. 67-124.

SRDI (2018). Land and soil resource Utilization Guide(In Bengali). Upazila Nirdeshica SeriesMadhupur Upazila, Soil Resource Development institute, Ministry of Agriculture, Dhaka.

Uddin N, Islam MA, Baten MA (2016). Heavy metal determination of brinjal cultivated in Soil with wastes. Progressive Agriculture, 27 (4): 453-465.

Walkley AJ, Black IA (1934). Estimation of soil organic carbon by the chromic acid titration method. Soil Science, 37: 29-38. 